\title{
IMPLEMENTASI KEBIJAKAN SISTEM KELAS TUNTAS BERKELANJUTAN (SKTB) DI SMP NEGERI 4 SUNGGUMINASA
}

\author{
Herli1 $^{1}$, Muhlis Madani ${ }^{2}$, Fatmawati ${ }^{3}$ \\ ${ }^{1,2,3}$ Universitas Muhammadiyah Makassar, Indonesia \\ email: herli.57388@gmail.com
}

\begin{abstract}
Abstrak
Kebijakan Sistem Kelas Tuntas Berkelanjutan (SKTB) di SMP Negeri 4 Sungguminasa dengan beberapa variabel yang mempengaruhi pelaksanaan kebijakan perilaku hubungan antar organisasi, perilaku pelaksana tingkat bawah dan perilaku kelompok sasaran. Metode yang digunakan dalam penelitian ini adalah pendekatan deskriptif kualitatif dengan menggunakan instrumen observasi, wawancara dan dokumentasi. Kemudian teknik analisis data melalui reduksi data, penyajian data dan penarikan kesimpulan. Hasil penelitian menunjukkan bahwa: (1) adanya komitmen dan koordinasi yang baik antara Dinas Pendidikan Kabupaten Gowa dengan SMP Negeri 4 Sungguminasa. Komitmen Dinas Pendidikan Kabupaten Gowa ditunjukkan pada kegiatan supervisi dan pembimbingan yang dilakukan oleh Pengawas Bina pada kepala sekolah dan guru SMP Negeri 4 Sungguminasa. DPRD Kabupaten Gowa sebagai lembaga legislatif berfungsi sebagai lembaga yang mengawasi jalannya kebijakan SKTB di Kabupaten Gowa mengawal kebijakan SKTB dengan melakukan pemantauan dan koordinasi dengan Dinas Pendidikan Kabupaten Gowa. (2) Fungsi kontrol yang dilakukan dalam administrasi maupun dalam proses pembelajaran dengan melakukan supervisi dan evaluasi secara berkala kepada guru.(3) Adanya dukungan positif dari guru dan siswa terhadap pelaksanaan kebijakan SKTB dengan adanya kesediaan guru melaksanakan administrasi pembelajaran dan penilaian pembelajaran serta evaluasi penilaian melalui program remisi dan pengayaan.
\end{abstract}

Keywords: Implementasi, Kebijakan, Sistem Kelas Tuntas Berkelanjutan

\begin{abstract}
Policy on the Automated Promotion System (SKTB) at SMP Negeri 4 Sungguminasa with several variables that influence the implementation of the inter-organizational relationship behavior policy, the behavior of lower level implementers and the behavior of the target group. The method used in this study is a qualitative descriptive approach using the instruments of observation, interviews and documentation. Then data analysis techniques through data reduction, data presentation and drawing conclusions. The results showed that: (1) there was a good commitment and coordination between the Gowa Regency Education Office and SMP Negeri 4 Sungguminasa. The commitment of the Gowa District Education Office is shown in the supervision and guidance activities carried out by the Superintendent of Development for the principal and teachers of SMP Negeri 4 Sungguminasa. The Gowa Regency DPRD as a legislative body functions as an institution that oversees the implementation of the SKTB policy in Gowa Regency, overseeing the SKTB policy by monitoring and coordinating with the Gowa Regency Education Office. (2) The control function is carried out in administration and in the learning process by conducting regular supervision and evaluation of teachers. (3) There is positive support from teachers and students for the implementation of the SKTB policy with the teacher's willingness to carry out learning administration and learning assessments as well as assessment evaluations. through remission and enrichment programs.
\end{abstract}

Keywords: Implementation, Policy, Automated Promotion Systems

\section{PENDAHULUAN}

Bidang pendidikan merupakan urusan pemerintah daerah dalam kewenangannya sebagai bagian dari desentralisasi dari pusat. Daerah mampu meningkatkan kualitas sumber daya manusia apabila didukung dengan peningkatan program di bidang pendidikan. Tolok ukur kualitas sumber daya manusia berada pada kemampuan daerah dalam menghasilkan program di bidang pendidikan. Program di bidang pendidikan diharapkan dapat mewujudkan daerah menjadi 
berkembang, berdaya saing dan maju serta masyarakat yang sejahtera. Keniscayaan bagi pemerintah daerah untuk mampu menyusun kebijakan pendidikan yang sesuai dengan kondisi dan kebutuhan lokal. Sehingga kebijakan di sektor pendidikan mesti menjadi skala prioritas dalam pembangunan daerah.

Kabupaten Gowa sebagai daerah penyangga ibukota Provinsi Sulawesi Selatan berupaya meningkatkan kualitas sumber daya manusia melalui bidang pendidikan. Di bawah kepemimpinan Ichsan Yasin Limpo, Kabupaten Gowa pada tahun 2013 mengeluarkan kebijakan di bidang pendidikan melalui Dinas Pendidikan, Pemuda dan Olah Raga Kabupaten Gowa yaitu penerapan Sistem Kelas Tuntas Berkelanjutan. Kebijakan program Sistem Kelas Tuntas Berkelanjutan (SKTB) diatur dalam Peraturan Daerah Nomor 10 Tahun 2013. Sebelum diatur melalui Peraturan Daerah, Sistem Kelas Tuntas Berkelanjutan (SKTB) telah disosialisasikan sejak tahun 2011 dengan menjadikan 50 buah sekolah di tingkat SD, SMP dan SMA/SMK sebagai proyek percontohan.

Dalam penerapannya ditemukan permasalahan yang berkaitan dengan pelaksanaan kebijakan SKTB yang belum terlaksana secara menyeluruh karena masih adanya pemahaman pelaksana kebijakan Sistem Kelas Tuntas Berkelanjutan (SKTB) yang masih kurang. Sehingga hal tersebut mengakibatkan tidak semua program yang diimplementasikan dapat berlangsung secara optimal dan efektif. Gejala inilah mengakibatkan terjadinya implementation gap menurut Dunn (dalam Solichin, 1997). Suatu istilah yang menjelaskan suatu keadaan di mana dalam proses kebijakan yang memunculkan kemungkinan terjadinya perbedaan antara apa yang diharapkan (direncanakan) oleh pembuat kebijakan dengan apa yang nyata tercapai (sebagai hasil atau prestasi dari pelaksanaan kebijakan).

Konsep Sistem Kelas Tuntas

Berkelanjutan (SKTB) merupakan konsep yang dicetuskan oleh Pemerintah Daerah Kabupaten Gowa dengan terbitnya Peraturan Daerah Kabupaten Gowa Nomor 10 Tahun 2013 tentang Sistem Kelas Tuntas Berkelanjutan. Sistem Kelas Tuntas Berkelanjutan (SKTB) adalah kebijakan program pendidikan Pemerintah Daerah Kabupaten Gowa yang berupaya memberikan pelayanan pendidikan secara optimal kepada peserta didik melalui strategi penuntasan semua standar kompetensi dan kompetensi dasar pada setiap mata pelajaran.

Secara operasional, SKTB diartikan bahwa peserta didik dapat mencapai ketuntasan dalam mencapai kualitas suatu mata pelajaran pada kelas yang diikuti dan keberlanjutan dalam mengikuti kelas dan jenjang pendidikan berikutnya (SKTB, 2013).

\section{TINJAUAN PUSTAKA}

Jika merujuk pada kamus Webster (Tachjan, 2006), kata implementasi secara etimologis dirumuskan secara pendek yakni (1) to carry into effect; to fulfill; accomplish. (2) to provide with the means for carrying out into effect or fulfilling; to give practical effect to. (3) to provide or equip with implements". (Artinya: (1) to implement dimaksudkan "membawa ke suatu hasil (akibat); melengkapi dan menyelesaikan"; (2) to implement dimaksudkan "menyediakan sarana (alat) untuk melaksanakan sesuatu; memberikan hasil yang bersifat praktis terhadap sesuatu"; (3) to implement dimaksudkan menyediakan atau melengkapi dengan alat). Dalam Kamus Besar Bahasa Indonesia, implementasi adalah pelaksanaan, penerapan. Dari segi bahasa, implementasi diartikan sebagai pelaksanaan, penerapan, atau pemenuhan. Begitu pula implementasi kebijakan merupakan tahapan bersifat praktis berbeda dengan formulasi rumusan masalah atau perumusan kebijakan sebagai tahapan yang bersifat teoritis.

Dunn (2003) memberikan argumennya tentang implementasi kebijakan sebagai berikut: "Policy implementation is essentially a practical activity, as distinguished from policy formulation which is essentially theorical." Sehubungan dengan sifat praktis yang ada dalam proses implementasi kebijakan, maka hal yang wajar bahwa implementasi ini berkaitan dengan proses politik dan administrasi. Hal tersebut disebabkan karena terkait dengan tujuan diadakannya kebijakan (policy goals).

Winter (Hill and Hupe, 2002) mengemukakan bahwa terdapat 3 (tiga) variabel yang mempengaruhi keberhasilan proses implementasi, yakni: 1) Adanya perilaku organisasi dan antar organisasi yang ditunjukkan pada dimensi tingkat komitmen 
dan koordinasi, 2) adanya perilaku implementor tingkat bawah (street-level bureucrats) dengan menggunakan dimensi kontrol politik, kontrol organisasi, etos kerja dan norma-norma profesional dan 3) Adanya perilaku kelompok sasaran. Perilaku kelompok sasaran tidak hanya memberikan dampak pada efektivitas implementasi kebijakan, tetapi juga mencakup respon positif atau respon negatif masyarakat untuk mendukung atau tidak mendukung suatu kebijakan dengan adanya umpan balik dari kelompok sasaran terhadap kebijakan yang dibuat.

\section{METODE PENELITIAN}

Penelitian ini menggunakan pendekatan deskriptif kualitatif dengan jenis penelitian studi kasus yang dipadukan dengan teknik triangulasi. Pendekatan kualitatif dipilih karena dapat memperoleh pemahaman pada sebuah fenomena yang belum diketahui. Pendekatan deskriptif digunakan untuk mengkaji data yang diperoleh dari observasi dan hasil wawancara yang mendalam (indepth interview).

Penelitian ini berlokasi di SMP Negeri 4 Sungguminasa Kabupaten Gowa. Adapun teknik dalam pengumpulan data adalah sebagai berikut: observasi, studi dokumentasi dan wawancara. Pada langkah selanjutnya adalah melakukan proses analisis yaitu: reduksi data, verifikasi data dan penarikan kesimpulan. Uji keabsahan data dilakukan melalui perpanjangan masa pengamatan, teknik peningkatan ketekunan dan triangulasi.

\section{HASIL DAN PEMBAHASAN}

\section{Perilaku Hubungan Antar Organisasi}

Dua aspek yang mempengaruhi keberhasilan implementasi kebijakan dalam hubungan antar organisasi yaitu komitmen dan koordinasi. Komitmen organisasi terkait sudah jelas yakni meningkatnya mutu pendidikan di SMP Negeri 4 Sungguminasa Kabupaten Gowa. Cheema dan Rondinelli dalam (Subarsono, 2005) karakteristik dan kapabilitas agen pelaksana tergambar bagaimana komitmen pelaksana terhadap kebijakan SKTB. Komitmen Dinas Pendidikan Kabupaten Gowa dan SMP Negeri 4 Sungguminasa ini sudah baik dalam hal komitmen organisasi guna meningkatkan mutu pendidikan di SMP Negeri 4 Sungguminasa. DPRD Kabupaten Gowa sebagai lembaga legislatif berfungsi sebagai lembaga yang mengawasi jalannya kebijakan SKTB di Kabupaten Gowa mengawal kebijakan SKTB dengan melakukan pemantauan dan koordinasi dengan Dinas Pendidikan Kabupaten Gowa. Hal tersebut ditunjukkan pada upaya evaluasi terhadap pelaksanaan kebijakan SKTB secara menyeluruh di seluruh satuan pendidikan tingkat SD dan SMP oleh Dinas Pendidikan Kabupaten Gowa yang dilaporkan pada rapat dengar pendapat dengan komisi IV DPRD Kabupaten Gowa.

Dalam rangka menjaga komitmen antar organisasi dalam meningkatkan mutu pendidikan melalui kebijakan SKTB maka diperlukan upaya koordinasi antar organisasi. Hasil penelitian menunjukkan bahwa Kepala SMP Negeri 4 Sungguminasa selaku aktor pelaksana di tingkat satuan pendidikan menunjukkan upaya koordinasi dengan Dinas Pendidikan Kabupaten Gowa melalui Pengawas Bina yang ditugaskan di SMP Negeri 4 Sungguminasa. Koordinasi yang dilakukan adalah konsultasi dan pembimbingan. Dalam menjalankan tupoksi pengawas, maka Pengawas Bina pada SMP Negeri 4 Sungguminasa melakukan supervisi dan melakukan bimbingan baik secara administratif maupun secara proses pembelajaran. Hal tersebut ditunjukkan pada kesiapan dokumentasi administrasi yang berkaitan dengan keberhasilan pelaksanaan kebijakan SKTB di SMP Negeri 4 Sungguminasa.

\section{Perilaku Pelaksana Tingkat Bawah}

Dalam meningkatkan kualitas pendidikan di SMP Negeri 4 Sungguminasa dengan menerapkan kebijakan SKTB, maka fungsi kontrol yang dilakukan oleh Kepala Sekolah kepada guru dan siswa baik dalam administrasi maupun dalam proses pembelajaran. Sehingga guru selaku target sasaran dalam kebijakan SKTB di SMP Negeri 4 Sungguminasa dapat menjalankan fungsinya dengan baik sesuai dengan tugas pokok dan fungsinya. Secara berkala melalui rapat bulanan, guru melaporkan tugas-tugas pengajarannya kepada kepala sekolah. Pada awal tahun pelajaran, kepala sekolah dibantu oleh Wakil Kepala Sekolah Bidang Kurikulum 
melakukan deteksi awal kesiapan pembelajaran guru dalam pembelajaran tahun pelajaran yang akan berjalan. Pada setiap jeda semester, Wakil Kepala Sekolah Bidang Kurikulum melakukan supervisi untuk mengetahui sejauh mana capaian keberhasilan penerapan kebijakan SKTB dalam proses pembelajaran. Sehingga dengan demikian dapat disimpulkan bahwa kontrol organisasi dalam implementasi kebijakan sudah berjalan dengan baik.

Dengan berjalannya fungsi kontrol organisasi, maka upaya peningkatan kualitas Sumber Daya Manusia (SDM) dapat berjalan dengan baik. Faktor SDM merupakan penentu keberhasilan implementasi kebijakan secara efektif. Edward III ((Ismaya \& Supriyadi, 2020) mengemukakan apabila implementor kekurangan sumberdaya untuk melaksanakan, implementasi tidak akan berjalan efektif. Sumberdaya tersebut dapat berwujud sumberdaya manusia, yakni kompetensi implementor, dan sumberdaya finansial. Implementasi kebijakan mengalami hambatan karena faktor profesionalisme yang masih kurang dalam pelaksanaan kebijakan SKTB di SMP Negeri 4 Sungguminasa. Hal tersebut ditunjukkan dengan belum memadainya jumlah guru yang berstatus PNS dan belum semuanya memahami SKTB dengan baik.

Merilee S. Grindle dalam (Nugroho, 2009) menjelaskan bahwa untuk mengimplementasikan isi kebijakan maka perlu memperhatikan sumber daya yang dikerahkan. Kendala jumlah guru yang berstatus PNS sebanyak 43 orang yang tidak sebanding jumlah siswa sebanyak 799 orang. Akibatnya dalam implementasi kebijakan SKTB di SMP Negeri 4 Sungguminasa belum berjalan secara optimal.

\section{Perilaku Kelompok Sasaran}

Dukungan publik penting dalam mempengaruhi keberhasilan implementasi sebuah kebijakan. Hasil penelitian menunjukkan guru dan siswa sebagai kelompok sasaran dalam implementasi kebijakan SKTB di SMP Negeri 4 Sungguminasa memberikan dukungan positif atas kebijakan yang dijalankan. Dukungan yang diberikan adalah kesediaan guru dalam menyiapkan perangkat proses pembelajaran dan menjalankan proses pembelajaran dengan kebijakan SKTB seperti melakukan deteksi dini terhadap kemampuan siswa dan menjadikan instrumen deteksi dini sebagai jajak awal terhadap kemampuan siswa. Bagi siswa, pelaksanaan remidi dan pengayaan dalam upaya menuntaskan kompetensi dasar memberikan motivasi belajar untuk meningkatkan kompetensinya.

Respon negatif dalam implementasi kebijakan bagai sisi mata uang yang tak dapat dipisahkan. Implementasi kebijakan SKTB di SMP Negeri 4 Sungguminasa direspon negatif dengan masih ditemukan pemahaman tidak tinggal kelas di kalangan siswa. Hal tersebut diakibatkan karena komunikasi berupa sosialisasi kebijakan SKTB belum optimal. Sehingga perlu adanya sosialisasi kebijakan SKTB dengan baik kepada siswa yang masih memiliki pemahaman tersebut.

\section{KESIMPULAN}

Berdasarkan hasil pembahasan pada bagian sebelumnya, maka dapat diperoleh kesimpulan sebagai berikut:

a. Perilaku Hubungan Organisasi

Komitmen Dinas Pendidikan Kabupaten Gowa dan SMP Negeri 4 Sungguminasa ini sudah baik dalam hal komitmen organissssasi guna meningkatkan mutu pendidikan di SMP Negeri 4 Sungguminasa. Sedangkan DPRD Kabupaten Gowa sebagai lembaga legislatif berfungsi sebagai lembaga yang mengawasi jalannya kebijakan SKTB di Kabupaten Gowa mengawal kebijakan SKTB dengan melakukan pemantauan dan koordinasi dengan Dinas Pendidikan Kabupaten Gowa.

b. Perilaku Pelaksana Tingkat Bawah

Fungsi kontrol yang dilakukan oleh Kepala Sekolah kepada guru dan siswa baik dalam administrasi maupun dalam proses pembelajaran. Kepala sekolah dibantu oleh Wakil Kepala Sekolah Bidang Kurikulum melakukan supervisi dan evaluasi secara berkala kepada guru. Implementasi kebijakan mengalami hambatan karena faktor profesionalisme yang masih kurang dalam pelaksanaan kebijakan SKTB di SMP Negeri 4 Sungguminasa. Kendala jumlah guru yang berstatus PNS sebanyak 43 orang yang 
tidak sebanding jumlah siswa sebanyak 799 orang. Akibatnya dalam implementasi kebijakan SKTB di SMP Negeri 4 Sungguminasa belum berjalan secara optimal.

c. Perilaku Kelompok Sasaran

Guru dan siswa sebagai kelompok sasaran dalam implementasi kebijakan SKTB di SMP Negeri 4 Sungguminasa memberikan dukungan positif atas kebijakan yang dijalankan. Dukungan yang diberikan adalah kesediaan guru dalam menyiapkan perangkat proses pembelajaran dan menjalankan proses pembelajaran dengan kebijakan SKTB seperti melakukan deteksi dini terhadap kemampuan siswa. Bagi siswa, pelaksanaan remidi dan pengayaan dalam upaya menuntaskan kompetensi dasar memberikan motivasi belajar untuk meningkatkan kompetensinya.

Masih ditemukan pemahaman tidak tinggal kelas di kalangan siswa SMP Negeri 4 Sungguminasa. Hal tersebut diakibatkan karena komunikasi berupa sosialisasi kebijakan SKTB belum optimal. Sehingga perlu adanya sosialisasi kebijakan SKTB dengan baik kepada siswa yang masih memiliki pemahaman tersebut.

\section{REFERENSI}

Dunn, W. N. (2003). Pengantar Analisis Kebijakan Pulblik Edisi Kedua (2003rd ed.). UGM Press.

Hill and Hupe, M. and P. (2002). Implementing Public Policy. SAGE Publications Ltd.

Ismaya, B., \& Supriyadi, D. (2020). Manajemen Kebijakan Pendidikan. Refika Aditama.

Nugroho, R. (2009). Public Policy (Edisi Revisi). Elex Media Komputindo.

SKTB, T. (2013). Naskah Akademik Sistem Kelas Tuntas Berkelanjutan (Automatic Promotion) (2013th ed.). Dinas Pendidikan Olah Raga dan Pemuda.

Solichin, A. W. (1997). Evaluasi Kebijakan Publik. PT. Bumi Aksara.
Subarsono, A. (2005). Analisis Kebijakan Publik. Pustaka Pelajar.

Tachjan. (2006). Implementasi Kebijakan Publik. Asosiasi Ilmu Politik Indonesia (AIPI) Bandung.

\section{Dokumen}

Undang-Undang Nomor 20 Tahun 2003, Tentang Sistem Pendidikan Nasional. Dokumen Negara RI.

Peraturan Daerah Kabupaten Gowa Nomor 10 Tahun 2013 tentang Sistem Kelas Tuntas Berkelanjutan (SKTB) 